\title{
Electrolyte and acid-base imbalance in native calves with enteropathogenic diarrhea
}

\author{
Seongwoo Kang ${ }^{1, \dagger}$, Jinho Park ${ }^{2, \dagger}$, Kyoung-Seong Choi ${ }^{3}$, Kwang-Man Park $^{2}$, Jin-Hee Kang ${ }^{2}$, \\ Dong-In Jung ${ }^{1}$, Dohyeon Yu ${ }^{1, *}$ \\ ${ }^{1}$ College of Veterinary Medicine, Gyeongsang National University, Jinju 52828, Korea \\ ${ }^{2}$ College of Veterinary Medicine, Jeonbuk National University, Iksan 54596, Korea \\ ${ }^{3}$ College of Ecology and Environmental Science, Kyungpook National University, Sangju 37224, Korea
}

\begin{abstract}
Diarrhea is the most common cause of death in calves, and remains a major health challenge. Although there are many studies on the related pathogens, the understanding of the clinicopathological changes is limited. This study aimed to identify the pathogens and observe the clinicopathological changes in electrolytes and acute phase proteins (APPs) associated with diarrhea. Blood samples and fecal samples were collected from 141 calves for the determination of APPs, electrolyte and acid-base status and identification of enteropathogens, respectively. Single or co-infections with enteropathogens, including virus (bovine viral diarrhea virus, coronavirus, and rotavirus), Eimeria, Cryptosporidium, and Escherichia coli K99 were detected in both non-diarrheic and diarrheic calves. Levels of APPs such as serum amyloid A, haptoglobin and fibrinogen were comparable between diarrheic and nondiarrheic calves. Hypoglycemia, high blood urea, electrolytes and acid-base imbalance (hyponatremia, hypochloremia, and decreased bicarbonate), and strong ion difference (SID) acidosis showed a significant association in diarrheic calves $(p<0.01)$. Particularly, significant hyponatremia, bicarbonate loss, SID acidosis, hypoglycemia, and elevated blood urea nitrogen were found in rotavirusinfected calves. Monitoring the clinicopathological parameters of APPs and electrolyte levels could be vital in the clinical management of diarrheic calves.
\end{abstract}

Keywords: cattle, diarrhea, electrolytes, acid-base imbalance, acute-phase proteins

*Corresponding author

Dohyeon Yu

College of Veterinary Medicine, Gyeongsang

National University, 501 Jinju-daero, Jinju 52828, Korea.

Tel: $+82-55-772-2368$

Fax: +82-55-772-2330

E-mail: yudh@gnu.ac.kr

These authors contribute equally to this work.

Conflict of Interest

The authors declare no conflicts of interest.

ORCID

Seongwoo Kang

https://orcid.org/0000-0001-9893-9275

Jinho Park

https://orcid.org/0000-0001-5235-5717

Kyoung-Seong Choi

https://orcid.org/0000-0002-2271-5360

Dohyeon $\mathrm{Yu}$

https://orcid.org/0000-0001-7645-6926

Received: April 23, 2020

Revised: June 16, 2020

Accepted: July 10, 2020

\section{Introduction}

Diarrhea is the most common cause of mortality in young calves, and therefore amounts to productivity and economic losses to the livestock industry. Despite our knowledge of the pathophysiology of calf diarrhea and technologies available for the identification of pathogens, its management remains a major challenge. Currently, Escherichia coli K99, Cryptosporidium, bovine rotavirus (BRV), and coronavirus have been found to be associated with calf diarrhea [1].

Most enteropathogens are known to cause both secretory and malabsorptive types of diarrhea. In secretory diarrhea, toxins from the enteropathogens, namely BRV and E. coli K99 induce secretion of sodium, chloride, and water into the intestinal lumen. Virus infection destroys mature enterocytes in villi causing villous atrophy, consequently decreasing the intestinal surface area for effective absorption of food. Following this, malabsorptive diarrhea sets in; unabsorbed glucose and other carbohydrates create an osmotic load pulling fluid into the lumen resulting in an increased fluid secretion from the crypts into the intestinal lumen relative to villous absorption, leading to diarrhea [2]. Loss of water and bicarbonates along with a decreased glomerular filtration rate in chronic diarrhea causes acid-base disturbances [3,4]. A decrease in strong ion difference (SID) is directly responsible for strong ion acidosis and acidemia, and therefore there has been a growing interest in studying the SID of electrolytes [5].

Acute-phase proteins (APPs) are a class of blood proteins whose concentration changes when animals are subjected to external or internal challenges, including infection, inflammation, surgical trauma, or stress. During an infection or tissue damage, the production of APPs increases in the liver, commonly referred to as acute-phase response [6]. APPs are considered as non- 
specific innate immune components that contribute to the restoration of homeostasis and inhibition of microbial growth [7]. Serum amyloid A (SAA) [8], haptoglobin (Hp) [9] and fibrinogen $(\mathrm{Fb})[7,10]$ are some of the common APPs in catthe that are routinely used in diagnostic studies in cattle.

The purpose of this study was to investigate the pathogendependent changes in electrolyte levels and acid-base imbalance in diarrheic and non-diarrheic calves. We hypothesized that the analysis of APPs (SAA, Hp, Fb), electrolytes, and acid-base status could be managed better based on the identified causative enteropathogen.

\section{Materials and Methods}

One-hundred and forty-two diarrheic and non-diarrheic calves from nine farms in different parts of Korea were selected for this study (Korean native cattle, $\mathrm{n}=119$; Holstein, $\mathrm{n}=23$ ). The calves consisted of diarrheic and non-diarrheic calves. Blood samples were collected by venipuncture of the jugular vein using a $19 \mathrm{G}$ needle and stored in an EDTA vacutainer tube for complete blood cell count and in a serum separator vacutainer tube for collecting serum. The blood was immediately centrifuged at $3,000 \times g$ for $15 \mathrm{~min}$ at $4^{\circ} \mathrm{C}$ to harvest serum. Fecal samples were collected by rectal examination, and fecal score above 3 based on the Wisconsin university criteria was regarded as diarrhea (https:// www.vetmed.wisc.edu/fapm/svm-dairy-apps/calf-healthscorer-chs).

Infections by enteropathogens, namely Cryptosporidium,
E. coli K99, Salmonella, bovine coronavirus (BCV), bovine viral diarrhea virus (BVDV), BRV, and Eimeria, were considered as major risk factors for diarrhea in calves. The RNA was extracted from the feces using Trizol reagent (Takara, Japan) according to the manufacturer's instructions. Single real time-polymerase chain reaction (RT-PCR) was performed using a one-step RT-PCR mixture (SolGent ${ }^{\mathrm{TM}}$, Korea) and previously reported primers for the detection of specific genes for BCV, BRV, and BVDV [10-12]. Eimeria was detected by fecal examination.

The SAA, Hp, and $\mathrm{Fb}$ were measured using commercially available ELISA kits (Phase SAA, haptoglobin, Tridelta Development, Maynooth, Co, Ireland). Total protein in plasma and serum was measured using a refractometer (Rhino VET 360 Refractometer, Reichert Analytic instruments), and the difference obtained was considered as the fibrinogen concentration. Serum concentrations of glucose, blood urea nitrogen (BUN), sodium $\left(\mathrm{Na}^{+}\right)$, chloride $\left(\mathrm{Cl}^{-}\right)$, potassium $\left(\mathrm{K}^{+}\right)$, bicarbonate $\left(\mathrm{HCO}_{3}^{-}\right), \mathrm{pH}$, and partial pressure of $\mathrm{CO}_{2}$ were measured using the i-stat portable clinical analyzer with CHEM8+ cartridges (Abbott Laboratories, USA). In order to evaluate strong ion acidosis or acidemia [13], SID was calculated based on the number of strong ions measured in serum as per the formula:

$$
\mathrm{SID}=\left(\left[\mathrm{Na}^{+}\right]+\left[\mathrm{K}^{+}\right]\right)-\left[\mathrm{Cl}^{-}\right] .
$$

Statistical analysis was performed using Statistical Package for the Social Sciences (IBM SPSS, Windows, Version 21.0, USA). The normality test was conducted using Kolm-

Table 1. Enteropathogens from 141 calves consisting of 109 (77.3\%) non-diarrheic calves and $32(22.7 \%)$ diarrheic calves

\begin{tabular}{|c|c|c|c|c|}
\hline Infection type & Pathogens & $\begin{array}{l}\text { Non-diarrheic calves } \\
(\mathrm{n}=109)\end{array}$ & Pathogens & $\begin{array}{l}\text { Diarrheic calves } \\
\quad(\mathrm{n}=32)\end{array}$ \\
\hline None & none & 36 & None & 6 \\
\hline \multirow[t]{2}{*}{ Virus } & $\mathrm{BCV}$ & 18 & & \\
\hline & BVDV & 14 & BVDC & 4 \\
\hline \multirow[t]{2}{*}{ Parasite } & Eimeria & 7 & Eimeria & 2 \\
\hline & Cryptosporidium & 1 & & \\
\hline \multirow[t]{3}{*}{ Virus + virus } & $\mathrm{BCV}+\mathrm{BVDV}$ & 15 & $\mathrm{BCV}+\mathrm{BVDV}$ & 6 \\
\hline & $\mathrm{BRV}+\mathrm{BVDV}$ & 1 & $\mathrm{BRV}+\mathrm{BVDV}$ & 1 \\
\hline & $\mathrm{BCV}+\mathrm{BRV}$ & 1 & $\mathrm{BCV}+\mathrm{BRV}+\mathrm{BVDV}$ & 1 \\
\hline \multirow[t]{8}{*}{ Virus + parasite } & $\mathrm{BCV}+$ Eimeria & 2 & $\mathrm{BCV}+$ Eimeria & 1 \\
\hline & BVDV + Eimeria & 4 & BVDV + Eimeria & 2 \\
\hline & BCV + Crypto & 1 & $\mathrm{BCV}+$ Crypto & 1 \\
\hline & Crypto + Eimeria + BVD & 1 & BVDV + Crypto & 2 \\
\hline & $\mathrm{BRV}+\mathrm{BVDV}+$ Eimeria & 1 & $\mathrm{BCV}+\mathrm{BVDV}+$ Eimeria & 1 \\
\hline & $\mathrm{BCV}+$ Eimeria + Crypto & 1 & BVDV + Crypto + Eimeria & 2 \\
\hline & $\mathrm{BCV}+\mathrm{BVDV}+$ Eimeria & 4 & BCV + BRV + BVDV + Crypto & 1 \\
\hline & BCV + BVDV + Crypto + Eimeria & 1 & $\begin{array}{l}\mathrm{BCV}+\mathrm{BRV}+\text { Crypto }+ \text { Eimeria } \\
\mathrm{BCV}+\mathrm{BRV}+\mathrm{BVDV}+\text { Crypto }+ \text { Eimeria } 1\end{array}$ & 1 \\
\hline $\begin{array}{l}\text { Virus }+ \text { parasite } \\
+ \text { bacteria }\end{array}$ & $\begin{array}{l}\mathrm{BCV}+\mathrm{BVDV}+\text { Cryptosporidium }+ \\
\text { Escherichia coli } \mathrm{K} 99\end{array}$ & 1 & & \\
\hline
\end{tabular}

$\mathrm{BCV}$, bovine coronavirus; BVDV, bovine viral diarrhea virus; BRV, bovine rotavirus. 
ogorov-Smirnov and Shapiro-Wilk tests, while Mann-Whitney $U$-test was used to for comparisons within the groups. Furthermore, Kruskal-Wallis test was used to identify the differences in levels of APPs, electrolytes, and WBC counts depending on the nature of the infection.

\section{Results}

\section{Enteropathogens and diarrhea}

Fecal samples were collected from 141 calves, consisting of $109(77.3 \%)$ non-diarrheic calves and 32 (22.7\%) diarrheic calves, and were tested for enteropathogens. BVD, BCV, Eimeria, Cryptosporidium, BRV, and E. coli K99 were found in $44.7 \%(\mathrm{n}=63), 40.4 \%(\mathrm{n}=57), 19.8 \%(\mathrm{n}=28)$, $9.9 \%(n=14), 4.9 \%(n=7)$, and $0.7 \%(n=1)$ of the samples, respectively; however, Salmonella could not be identified in any of the tested samples. Enteropathogens were detected in fecal samples from both diarrheic and non-diarrheic calves. In non-diarrheic calves, single pathogen infections were more common than co-infections, whereas infectious pathogens as part of co-infection were more common in diarrheic calves (Table 1).

Acute phase proteins, electrolytes, and acid-base laboratory analysis

The overall SAA, Hp and fibrinogen concentrations in calves with diarrhea were not statistically significant when compared to calves with non-diarrhea (Fig. 1). The levels of $\mathrm{Fb}$ were significantly increased in calves with diarrhea $(p=0.033)$ when infected with $\operatorname{BCV}(p=0.032)$ and Cryptosporidium $(p=0.011)$, but decreased significantly in case of Eimeria infection when compared with the corresponding non-diarrheic or infected/non-infected group $(p=0.042)$

The electrolyte and acid-base imbalance analysis calves
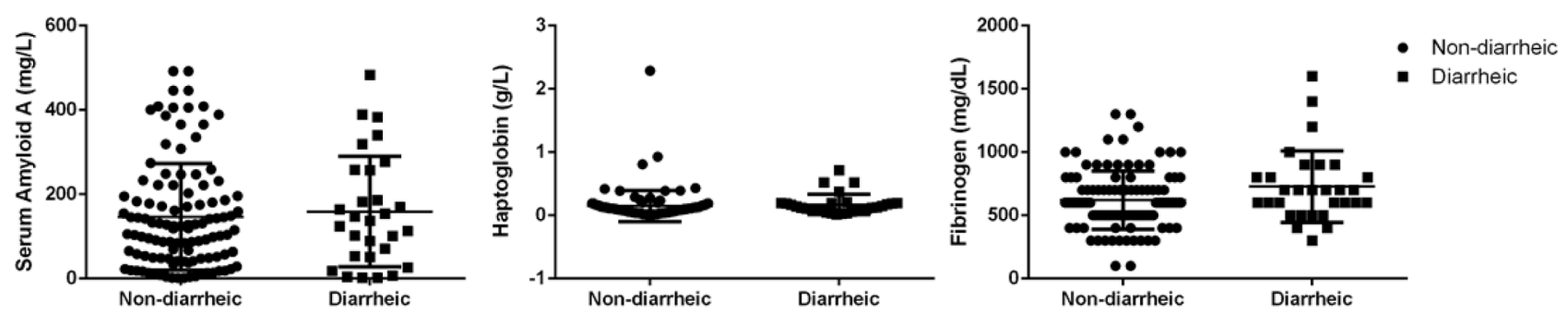

Fig. 1. Comparison of levels of acute phase proteins in diarrheic and non-diarrheic calves. Serum amyloid A, haptoglobin and fibrinogen concentrations in calves with diarrhea were not statistically significant when compared to calves with non-diarrhea.

Table 2. Difference of intrinsic factors in calves whether or not be influence to extrinsic factors

\begin{tabular}{|c|c|c|c|c|c|c|}
\hline Parameter & $\mathrm{Na}^{+}$ & $\mathrm{Cl}^{-}$ & $\mathrm{HCO}_{3}^{-}$ & SID & Glucose & BUN \\
\hline $\begin{array}{l}\text { Diarrhea } \\
\text { Non-diarrhea } \\
\text { Diarrhea } \\
p \text { value }\end{array}$ & $\begin{array}{c}138.4 \pm 6.6 \\
135.3 \pm 4.8 \\
0.002\end{array}$ & $\begin{array}{c}102.0 \pm 9.2 \\
98.0 \pm 5.3 \\
0.021\end{array}$ & $\begin{array}{c}27.6 \pm 6.6 \\
25.8 \pm 5.1 \\
0.021\end{array}$ & $\begin{array}{c}41.1 \pm 9.9 \\
34.7 \pm 15.7 \\
0.003\end{array}$ & $\begin{array}{c}107.2 \pm 25.7 \\
86.2 \pm 22.1 \\
0.0004\end{array}$ & $\begin{array}{c}10.0 \pm 8.3 \\
13.3 \pm 9.5 \\
0.032\end{array}$ \\
\hline $\begin{array}{l}\text { BVDV } \\
\text { Non-diarrhea } \\
\text { Diarrhea } \\
p \text { value }\end{array}$ & $\begin{array}{c}137.9 \pm 5.4 \\
137.7 \pm 7.0 \\
0.297\end{array}$ & $\begin{array}{c}102.9 \pm 9.1 \\
101.0 \pm 10.6 \\
0.027\end{array}$ & $\begin{array}{c}25.8 \pm 5.1 \\
28.3 \pm 7.0 \\
0.053\end{array}$ & $\begin{array}{c}42.4 \pm 3.8 \\
38.0 \pm 14.4 \\
0.076\end{array}$ & $\begin{array}{c}102.4 \pm 22.8 \\
103.5 \pm 28.7 \\
0.633\end{array}$ & $\begin{array}{c}11.1 \pm 10.3 \\
10.3 \pm 7.3 \\
0.899\end{array}$ \\
\hline $\begin{array}{l}\mathrm{BCV} \\
\text { Non-diarrhea } \\
\text { Diarrhea } \\
p \text { value }\end{array}$ & $\begin{array}{c}138.3 \pm 7.0 \\
137.2 \pm 5.7 \\
0.474\end{array}$ & $\begin{array}{c}102.5 \pm 11.9 \\
100.9 \pm 7.0 \\
0.312\end{array}$ & $\begin{array}{c}28.0 \pm 6.6 \\
26.4 \pm 6.1 \\
0.086\end{array}$ & $\begin{array}{c}39.2 \pm 13.3 \\
40.2 \pm 9.2 \\
0.0007\end{array}$ & $\begin{array}{c}104.5 \pm 6.8 \\
100.9 \pm 26.4 \\
0.366\end{array}$ & $\begin{array}{r}9.4 \pm 6.8 \\
11.9 \pm 10.7 \\
0.066\end{array}$ \\
\hline $\begin{array}{l}\text { Eimeria } \\
\text { Non-diarrhea } \\
\text { Diarrhea } \\
p \text { value }\end{array}$ & $\begin{array}{c}137.8 \pm 6.6 \\
137.6 \pm 3.7 \\
0.340\end{array}$ & $\begin{array}{c}101.9 \pm 9.7 \\
101.0 \pm 12.5 \\
0.084\end{array}$ & $\begin{array}{c}27.3 \pm 6.5 \\
26.9 \pm 3.7 \\
0.869\end{array}$ & $\begin{array}{c}40.2 \pm 10.6 \\
35.9 \pm 18.0 \\
0.083\end{array}$ & $\begin{array}{c}102.7 \pm 26.6 \\
106.5 \pm 24.0 \\
0.465\end{array}$ & $\begin{array}{c}10.9 \pm 8.9 \\
8.2 \pm 4.5 \\
0.465\end{array}$ \\
\hline $\begin{array}{l}\text { Cryptosporidium } \\
\text { Non-diarrhea } \\
\text { Diarrhea } \\
p \text { value }\end{array}$ & $\begin{array}{c}138.0 \pm 6.6 \\
135.8 \pm 4.5 \\
0.143\end{array}$ & $\begin{array}{c}100.8 \pm 6.7 \\
99.8 \pm 2.8 \\
0.327\end{array}$ & $\begin{array}{c}27.5 \pm 6.6 \\
25.9 \pm 5.0 \\
0.368\end{array}$ & $\begin{array}{c}42.8 \pm 4.3 \\
38.4 \pm 12.2 \\
0.219\end{array}$ & $\begin{array}{c}105.4 \pm 26.0 \\
82.5 \pm 21.4 \\
0.004\end{array}$ & $\begin{array}{c}11.3 \pm 9.0 \\
10.9 \pm 9.0 \\
0.178\end{array}$ \\
\hline $\begin{array}{l}\mathrm{BRV} \\
\text { Non-diarrhea } \\
\text { Diarrhea } \\
p \text { value }\end{array}$ & $\begin{array}{c}138.1 \pm 6.4 \\
130.0 \pm 6.2 \\
0.007\end{array}$ & $\begin{array}{c}101.9 \pm 10.2 \\
101.5 \pm 2.1 \\
0.577\end{array}$ & $\begin{array}{c}27.4 \pm 6.3 \\
17.6 \pm 4.6 \\
0.005\end{array}$ & $\begin{array}{c}39.8 \pm 11.9 \\
35.4 \pm 4.8 \\
0.0001\end{array}$ & $\begin{array}{c}103.4 \pm 26.3 \\
84.6 \pm 15.6 \\
0.046\end{array}$ & $\begin{array}{c}10.1 \pm 8.5 \\
27.0 \pm 19.0 \\
0.007\end{array}$ \\
\hline
\end{tabular}

BVDV, bovine viral diarrhea virus; BCV, bovine coronavirus; BRV, bovine rotavirus; SID, strong ion difference; BUN, blood urea nitrogen. 
with diarrhea revealed hyponatremia $(p<0.01)$, hypochloremia $(p<0.05)$, decreased $\mathrm{HCO}_{3}^{-}(p<0.05)$, and SID acidosis $(p<0.01)$. Diarrhea in calves also resulted in significantly low glucose $(p<0.001)$ and high BUN concentrations $(p<$ $0.05)$. BRV-infected calves demonstrated similar results of hyponatremia $(p<0.01)$, decreased $\mathrm{HCO}_{3}^{-}(p<0.01)$, SID acidosis $(p<0.01)$, hypoglycemia $(p<0.05)$, and elevated BUN $(p<0.01)$ when compared to the BRV non-infected calves. BCV infection resulted in increased SID levels, but the other parameters were comparable with the results obtained in the BCV non-infected group. Glucose concentration was significantly lower in Cryptosporidium-infected calves, but other parameters were comparable. No statistically significant changes in electrolytes or APP levels were observed in calves infected with Eimeria, and BVDV (Table 2). Based on the results obtained, young diarrheic calves with BRV infection were found to have significant clinicopathological changes as compared to the non-diarrheic group.

\section{Discussion}

The results of the study revealed the various enteropathogens and their combinations causing diarrhea, and the consequent changes in clinicopathological correlations, electrolyte levels, blood chemistry, and APP levels. The incidences of $\mathrm{BCV}$ and BVDV infections were found to be higher than other infectious enteropathogens in our study. Furthermore, there were different clinicopathological changes observed between the diarrheic and non-diarrheic calves, despite having the same infectious condition. Diarrhea in calves is reportedly related not only to infectious factors, but also to the non-infectious factors, namely, weather, housing, and sanitation [14]. Diarrhea induces excessive fluid loss and malabsorption in the small intestine, and thus influences clinicopathological changes in calves [4].

A decrease in electrolytes such as $\mathrm{Na}^{+}, \mathrm{Cl}^{-}$, and $\mathrm{HCO}_{3}^{-}$has been shown in diarrheic calves due to excessive electrolyte loss and decreased intake of milk due to anorexia [4]. Moreover, hyponatremia causing a decrease in the SID values was observed in diarrheic calves. A decrease in the SID value indicates strong ion acidosis or acidemia, which is clinically important and acts as a signal to initiate therapy in the form of fluid administration in diarrheic calves [15]. Decreased $\mathrm{HCO}_{3}^{-}$concentration due to loss into the intestine contributes to metabolic acidosis in diarrheic calves. The preliminary changes in electrolytes are primarily due to secretory diarrhea, which is one of the characteristics of infectious diarrhea in calves. The BRV diarrhea results in severe electrolyte loss and acid-base imbalance, and therefore aggressive therapeutic interventions are necessary for such situations. A decrease in glucose concentration causing negative energy balance in diarrheic calves suggests malabsorption, which is another aspect of infectious diarrhea [1]. A significant increase in BUN concentration along with a decreased glomerular filtration rate due to dehydration con- tributing to acidemia and metabolic acidosis in diarrheic calves has been reported [3]. An increase in the APP levels has been earlier reported during infectious and inflammatory states, and a similar pattern was demonstrated in this study in calves with diarrhea and infections except for some variations. The SAA levels did not show any significant changes with respect to diarrheal or infectious conditions. SAA is an APP of considerable importance with noticeable increments of 10-100-fold in response to acute stimulation [16]; however, it did not change significantly with diarrhea and infections in this study. These results could be attributed to two reasons. A clinical sign, like diarrhea, does not always have a correlation with the severity of infection [1]. Secondly, production of APP is stimulated not only by infections, but also by the presence of other factors, namely, stress, trauma, tissue damage, and colostrum. SAA concentration in young calves has been shown to depend on a variety of factors. McDonald et al. [17] reported that factors such as birth trauma, intake of colostral inducers such as cytokines, and stress could increase SAA concentrations. The SAA concentration was found to be the highest in young calves, and it decreased significantly with age. No significant differences were observed in the Hp levels in calves with diarrhea and infections, for reasons similar to that of SAA. The results of this study further confirmed that the changes in APPs did not always reflect clinical severity of the disease condition.

This study has demonstrated the pattern of clinicopathological changes in each group based on the identified enteropathogen. Different etiologies result in various forms of diarrhea, and this accordingly influences the clinicopathological parameters. Therefore, the analysis of clinicopathological parameters provides key information for the identification of the pathogens, diarrheal condition, and its management.

\section{Acknowledgements}

This research was supported by Technology Development Program (Project No. 1116043-1) for Bio-industry, Ministry for Agriculture, Food and Rural Affairs, Republic of Korea.

\section{References}

1. Foster DM, Smith GW. Pathophysiology of diarrhea in calves. Vet Clin North Am Food Anim Pract 2009;25:13-36.

2. Argenzio RA. Pathophysiology of neonatal calf diarrhea. Vet Clin North Am Food Anim Pract 1985;1:461-469.

3. Groutides CP, Michell AR. Changes in plasma composition in calves surviving or dying from diarrhoea. Br Vet $\mathrm{J}$ 1990; 146:205-210.

4. Berchtold J. Intravenous fluid therapy of calves. Vet Clin North Am Food Anim Pract 1999;15:505-531.

5. Constable PD. A simplified strong ion model for acid-base equilibria: application to horse plasma. J Appl Physiol (1985) 1997;83:297-311.

6. Baumann H, Gauldie J. The acute phase response. Immunol Today 1994;15:74-80. 
7. Ceciliani F, Ceron JJ, Eckersall PD, Sauerwein H. Acute phase proteins in ruminants. J Proteomics 2012;75:4207-4231.

8. Horadagoda NU, Knox KM, Gibbs HA, Reid SW, Horadagoda A, Edwards SE, Eckersall PD. Acute phase proteins in cattle: discrimination between acute and chronic inflammation. Vet Rec 1999;144:437-441.

9. Murata H, Shimada N, Yoshioka M. Current research on acute phase proteins in veterinary diagnosis: an overview. Vet J 2004;168:28-40.

10. Tsunemitsu H, Smith DR, Saif LJ. Experimental inoculation of adult dairy cows with bovine coronavirus and detection of coronavirus in feces by RT-PCR. Arch Virol 1999;144:167175 .

11. Gentsch JR, Glass RI, Woods P, Gouvea V, Gorziglia M, Flores J, Das BK, Bhan MK. Identification of group A rotavirus gene 4 types by polymerase chain reaction. J Clin Microbiol 1992;30:1365-1373.

12. Vilček S, Herring AJ, Herring JA, Nettleton PF, Lowings JP, Paton DJ. Pestiviruses isolated from pigs, cattle and sheep can be allocated into at least three genogroups using polymerase chain reaction and restriction endonuclease analysis. Arch Virol 1994;136:309-323.

13. Constable PD. Clinical assessment of acid-base status. Strong ion difference theory. Vet Clin North Am Food Anim Pract 1999; 15:447-471.

14. Cho YI, Han JI, Wang C, Cooper V, Schwartz K, Engelken T, Yoon KJ. Case-control study of microbiological etiology associated with calf diarrhea. Vet Microbiol 2013;166:375385.

15. Koch A, Kaske M. Clinical efficacy of intravenous hypertonic saline solution or hypertonic bicarbonate solution in the treatment of inappetent calves with neonatal diarrhea. $\mathrm{J}$ Vet Intern Med 2008;22:202-211.

16. Eckersall PD, Bell R. Acute phase proteins: Biomarkers of infection and inflammation in veterinary medicine. Vet $\mathrm{J}$ 2010;185:23-27.

17. McDonald TL, Larson MA, Mack DR, Weber A. Elevated extrahepatic expression and secretion of mammary-associated serum amyloid A 3 (M-SAA3) into colostrum. Vet Immunol Immunopathol 2001;83:203-211. 